$(1 \cdot 26-1 \cdot 42 \mathrm{mmol} / 1 ; 5 \cdot 04-5 \cdot 68 \mathrm{mg} / 100 \mathrm{ml}) .{ }^{5}$ Those workers used a trometamol (TRIS) buffer which is highly temperature dependent, whereas this is not the case for the imidazole buffer that we employed. Their buffer was made up to $\mathrm{pH} 7.4$ at $37^{\circ} \mathrm{C}$ but used at room temperature. This would produce a rise in $\mathrm{pH}$ to roughly 7.7 at $25^{\circ} \mathrm{C}$, which would be associated with a fall of approximately $0.15 \mathrm{mmol} / 1(0.6 \mathrm{mg} / 100 \mathrm{ml})$ in the measurement of $\mathrm{CaD}$. As the mean of their reference range was $0.125 \mathrm{mmol} / 1(0.5 \mathrm{mg} / 100 \mathrm{ml})$ less than ours this technical difference may account for the differences in the normal ranges. This underlines the critical importance of the $\mathrm{pH}$ of the sample at which $\mathrm{CaD}$ is measured.

Another problem is that currently there is no internationally recognised reference standard for $\mathrm{CaD}$. Our approach has been to calibrate the assay system against a solution of calcium carbonate, but this is open to criticism as it does not allow for the Donnan effect of protein. Nevertheless, in view of the fact that large changes in serum albumin concentration induced by venous stasis had no effect on $\mathrm{CaD}$, the Donnan effect would appear to have no practical relevance. Although the problem of standardisation may be relevant to interpretation of results among different laboratories, once a standard has been developed within a particular laboratory the results will be internally consistent. Furthermore, if this method is widely accepted it should be possible to develop an acceptable international standard.

In favour of the use of $\mathrm{CaD}$ rather than other methods of calcium estimation is that the method is a simple modification of a continuous flow total calcium technique using equipment that has been tried and tested over many years and is readily available. It correlates well with $\mathrm{CaI}$ but has none of the practical problems associated with this technique. Although under many circumstances $\mathrm{CaA}$ gives a clinically equivalent result, calcula- tion requires the measurement of both $\mathrm{CaT}$ and albumin. Now that it is 50 years since the physiological irrelevance of protein associated calcium was first commented on it is time to move away from measuring $\mathrm{CaT}$. In busy biochemical laboratories $\mathrm{CaD}$ estimation is an efficient and cost effective answer.

We thank Mrs Margaret Miller, of the NH and MRC unit in clinical epidemiology, University of Western Australia, who provided some of the blood samples for analysis, and Miss Rowena Devlin, of the department of endocrinology and diabetes, Sir Charles Gairdner Hospital, who performed the CaI measurements.

\section{References}

McLean FC, Hastings AB. A biological method for the estimation of calcium ion concentration. $\mathcal{F}$ Biol Chem 1934;107:337-50.

Toffaletti J, Savory J, Gitelman HJ Continuous-flow determination of dialysable calcium in serum. Clin Chem 1977;23:1258-63.

Moore EW. Ionized calcium in normal serum, ultrafiltrates and whole blood determined by ion exchange electrodes. $\mathcal{F}$ Clin Invest 1970;49:318-34.

4 Toffaletti J, Bowers GN. Improvement in and clinical utility of a continuous-flow method for routine measurement of dialysable (ultrafiltrable) calcium. Clin Chem 1979;25:1939-43

5 Toffaletti J, Kirvan K. Spectrophotometric micromethod for measurement of dialysable calcium by use of cresolphthalein complexone and continuous-flow analysis. Clin Chem 1980;26:1562-5.

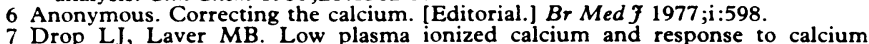
Drop LJ, Laver MB. Low plasma ionized calcium and response to calcium
therapy in critically ill man. Anesthesiology $1975 ; 43: 300-6$. therapy in critically ill man. Anesthesiology $1975 ; 43: 300-6$.
ayne RB. Clinically significant effect of protein concentration on ion-selective electrode measurements of ionized calcium. Ann Clin Biochem 1982;19:233-7.
conceicao SC, Weightman D, Smith PA, Luno J, Ward MK, Kerr DNS. Serum ionised calcium concentration: measurement versus calculation. Serum ionised calcium

10 Toffaletti J. Total, ultrafiltrable, dialysable and ionised calcium measurements in randomly selected samples compared with clinical diagnoses. Ann Clin Biochem $1983 ; 20: 349-52$.

11 Ladenson JH, Lewis JW, Boyd JC. Failure of total calcium corrected for protein, albumin and $\mathrm{pH}$ to correctly assess free calcium status. $\mathcal{F}$ Clin Endocrinol Metab $1978 ; 46: 986-93$.

(Accepted 30 October 1984)

\begin{abstract}
Naloxone abolished the rise in body temperature seen after bicycle ergometer tests performed by 10 healthy men. This suggests that endogenous opiates play a part in thermal regulation during muscular exercise.

\section{Introduction}

The effect of opiates on core temperature has been the subject of many studies. Evidence shows that endogenous opiates, in

Academisch Ziekenhuis, Vrije Universiteit Brussel, Belgium

$\mathrm{K}$ DE MEIRLEIR, MD, internist

L VANHAELST, MD, PHD, professor of endocrinology

Institut für Kreislaufforschung und Sportmedizin, Deutsche Sporthochschule, Cologne, Federal Republic of Germany T ARENTZ, medical student

W HOLLMANN, MD, PHD, professor of cardiology and sports medicine

Correspondence to: $\mathrm{Dr} \mathrm{K}$ De Meirleir, Internal Medicine, AZ-VUB, Laarbeeklaan 101, B-1090 Brussels, Belgium.
\end{abstract}

particular endorphins, have a role in the central control of body temperature. ${ }^{1-4}$ Because body temperature rises during dynamic muscular exercise we were intrigued to know whether endogenous opiates play a part in this phenomenon. We therefore studied the effect of naloxone (an opiate antagonist) on the changes in body temperature induced by exercise.

\section{Subjects, methods, and results}

Ten healthy men aged 22-28 years, who regularly participated in various sporting activities, underwent a graded ergometer test on three occasions. They exercised on a bicycle ergometer with electric brakes (Ergometric systems 380B, Siemens Elema, Sweden), and on each occasion an identical protocol was used. The tests were performed in the same laboratory at constant room temperature and humidity, at the same time of day, and with an interval of at least four days between each test for each subject.

The first test served as a control. In the second and third tests either placebo ( $5 \mathrm{ml}$ saline) or $2 \mathrm{mg}$ naloxone (naloxone hydrochloride $0.4 \mathrm{~g} / \mathrm{l}$, Dupont de Nemours, Belgium) was administered intravenously five minutes before exercising. The order of the placebo and naloxone tests was randomised and double blind; five subjects received placebo first and five received naloxone first to minimise carryover effects. The temperature in the laboratory was kept constant at $20^{\circ} \mathrm{C}$ and the humidity at $60 \%$. Sublingual temperature was 
Mean (SD) sublingual temperatures $\left({ }^{\circ} C\right)$ before, immediately after, and one hour after exercise in 10 healthy men given placebo or naloxone five minutes before exercise

\begin{tabular}{lccc}
\hline & Control & Placebo & Naloxone \\
\hline Before exercise & $36.85(0.24)$ & $36.64(0.28)$ & $36.58(0.29)$ \\
Immediately after & $37.33(0.26)$ & $37.16(0.27)$ & $36.40(0.54)^{*}$ \\
An hour after & $36.83(0.24)$ & $36.67(0.34)$ & $36.34(0.41)^{*}$ \\
\hline
\end{tabular}

$* \mathrm{p}<0.001$ compared with control and placebo studies.

measured with a simple thermometer before exercise, immediately afterwards, and one hour later. Statistical study of results was performed by two way analysis of variance.

There were no significant differences in maximal heart rate, maximal workload, or duration of exercise until exhaustion when the control, placebo, and naloxone trials were compared. As expected, a rise of body temperature of about $0.5^{\circ} \mathrm{C}$ was seen immediately after exercise in the control and placebo tests: mean sublingual temperature was $36.85(\mathrm{SD} 0.24)^{\circ} \mathrm{C}$ before and $37.33(0.86)^{\circ} \mathrm{C}$ after exercise in the control test and $36.64(0.28)^{\circ} \mathrm{C}$ before and $37.16(0.27)^{\circ} \mathrm{C}$ after exercise in the placebo test. Administration of naloxone completely abolished this rise in temperature: before exercise the sublingual temperature in the naloxone test was $36.58(0.29)^{\circ} \mathrm{C}$ and after $36.40(0.54)^{\circ} \mathrm{C}$. The difference between the placebo and control tests was significant $(\mathrm{p}<0.001)$ (table).

\section{Discussion}

Our finding that the rise in body temperature induced by exercise is antagonised by naloxone suggests that endogenous opiates play a part in thermal regulation during muscular exercise.

\section{References}

1 Yehuda S, Kastin A. Peptides and thermoregulation. Neuroscience and Biobehavioral Reviews 1979;4:459-71.

2 Holaday JW, Loh $\mathrm{HH}, \mathrm{Li} \mathrm{CH}$. Unique behavioural effects of beta endorphin and their relationship to thermoregulation and hypothalamic function. Life Sci 1978;22:1525-35.

3 Holaday JW, Wei E, Loh $\mathrm{HH}, \mathrm{Li} \mathrm{CH}$. Endorphins may function in heat adaptation. Proc Natl Acad Sci USA 1978;75:2923-7.

4 Clark WG. Changes in body temperature after administration of amino acids, peptides, dopamine, neuroleptics, and related agents. Neurosci Biobehav Rev $1980 ; 3: 179-231$.

(Accepted 21 November 1984)

\title{
Dihydrocodeine in renal failure: further evidence for an important role of the kidney in the handling of opioid drugs
}

\author{
J N BARNES, A J WILLIAMS, M J F TOMSON P A TOSELAND, F J GOODWIN
}

\begin{abstract}
The pharmacokinetics of a single oral dose of dihydrocodeine were studied in nine patients with chronic renal failure treated by haemodialysis and nine subjects with normal renal function. In the patients the mean peak plasma dihydrocodeine concentration occurred later and the area under the curve was greater than in the normal subjects. Furthermore, the drug was still detectable after 24 hours in all the patients but only three of the normal subjects.

These data, together with those obtained from previously published clinical case reports, contradict the traditional view that the body's ability to cope with opioid drugs is not altered in renal failure.
\end{abstract}

\section{Introduction}

The kidney is the main site for the elimination of many drugs and their metabolites from the body, and renal disease can consequently have important effects on the pharmacokinetics of such drugs. In addition, the pharmacokinetics of these drugs may be altered in uraemia by changes in plasma protein binding and the rates at which they are metabolised. ${ }^{12}$

Although opioid drugs and their metabolites are excreted by the kidney ${ }^{3}{ }^{4}$ and some have decreased plasma protein binding in uraemia, ${ }^{5}$ it is generally considered to be safe to prescribe them at the normal therapeutic dosage to patients with impaired renal function. ${ }^{6-8}$

This view must now be challenged. There have been several reports of serious narcosis in patients with renal failure treated with opioid drug, ${ }^{910}$ and evidence that the kidney has an important role in the elimination of opioid narcotics is accumulating. ${ }^{11} 12$

The present study was performed to investigate the effect of end stage renal failure on the pharmacokinetics of a single oral dose of dihydrocodeine, a drug that has hitherto been considered to be safe at the conventional dosage in patients with chronic renal failure receiving maintenance haemodialysis. ${ }^{13}$

\section{Subjects and methods}

We studied nine subjects (five men), mean (SD) age $34 \cdot 2(4 \cdot 2)$ years, with normal renal function and nine patients (seven men), age $40.8(5 \cdot 2)$ years, receiving maintenance haemodialysis. All the subjects attended after an overnight fast, and the patients attended on days when they were not receiving dialysis. A 19 G Butterfly cannula was inserted into a forearm vein in the normal subjects or into a vein on the back of the hand in the patients. Blood samples were taken immediately and without tourniquet for estimating plasma 